\title{
Evolution of the Concept of NATO Enlargement in the Period 1990-1997
}

\author{
Angel Yuliyanov Apostolov \\ Sofia University “St. Kliment Ohridski”, Faculty of History ${ }^{1}$
}

Received 30 March 2018 • Revised 20 June 2018 • Accepted 12 July 2018

\begin{abstract}
Since the end of the Cold War there had been an intense debate about whether NATO should invite countries from the former Soviet Bloc. While the potential admission of new members was only one aspect of the entire process of NATO transformation in the first decade after the end of the Cold War, it nevertheless sparked a number of debates that strongly influenced all other elements of the process. Candidate countries from Central Europe, in spite of being an external factor at first, also had a significant impact on the issue of NATO expansion and hence - on the overall transformation of the organization. If until 1997 NATO had mostly concentrated on the partnership approach both on a bilateral level or a multilateral level, so the period after 1997 was mostly focused on the membership of the post-communist states of Central and Eastern Europe. Contrary to the fears of many researchers and politicians, NATO's policy of enlargement not only had a positive influence on the consolidation of the newly founded democracies in Central and Eastern Europe, but the new members successfully contributed to the capabilities of the Alliance itself.
\end{abstract}

Keywords: evolution of concept, NATO, enlargement, transformation, Central and Eastern Europe.

\section{Introduction}

The accession of Hungary, Poland and the Czech Republic to NATO in 1999 was a milestone in the history of the Alliance. Since the end of the Cold War, there had been an intense debate about whether NATO should invite countries from the former Soviet Bloc. Finally, all NATO nations understood and accepted the need, which emerged from the new political and security context. The first round of enlargement after the fall of the Berlin Wall ${ }^{2}$ was a historic step in itself, but also opened the way for further rounds of accession in the following years (Hende, 2015). It should be noted that while the potential admission of new members was only one aspect of the entire process of NATO transformation in the first decade after the end of the Cold War, it nevertheless sparked a number of debates that strongly influenced all other elements of the

\footnotetext{
${ }^{1}$ The author is PhD student at the institution, and employed as Programs and Projects Expert in the Atlantic Club of Bulgaria.

2 NATO's membership did not "expand" in October 1990 when East Germany was absorbed into West Germany and simultaneously brought into the Alliance, as the number of NATO member states did not change.
}

(C) Authors. Terms and conditions of Creative Commons Attribution 4.0 International (CC BY 4.0) apply. Correspondence: Angel Apostolov, e-mail: apostolov.acb@gmail.com. 
process. And last but not least, candidate countries from Central Europe, in spite of being an external factor for the time being, also had a significant impact on the issue of NATO expansion and hence - on the overall transformation of the organization.

Undoubtedly, the start of this transformation was triggered by the end of the Cold War. The collapse of the Soviet Union didn't bring to the dissolution of the Alliance, even though many politicians and analysts considered its further existence pointless. Actually, from that point on, NATO ceased to be solely a collective defense union for deterrence of a powerful foreign adversary and therefore needed to build a new, definitive identity for itself in the context of radical political changes on a global scale. Most of all, the Alliance had to find its new place in the rapidly transforming architecture of international relations. As a result, NATO took on a new and much more complex role. It included establishing a partnership dialogue with the countries in Central and Eastern Europe and other countries in CSCE (OSCE, since 1995); developing constructive relationships with other international institutions that had a strong commitment to the European security such as the UN and WEU; as well as introducing new structures in the Allied military command and armed forces due to the changing security environment.

NATO embarked on the political and military transformation of its structures at the beginning of the 1990s. In July 1990, in a Summit declaration entitled the London Declaration on a Transformed North Atlantic Alliance, Allied leaders announced their intention of adapting the Alliance to the new security environment. A little over a year later, in November 1991 at the Rome Summit, they published a new strategic Concept and a Declaration on Peace and Cooperation. Together these documents charted the course for reorganizing and streamlining Alliance's political and military structures and procedures; reducing significantly Alliance's force and readiness levels; and reconfiguring Alliance's forces to make them better able to carry out the new missions of crisis management and peacekeeping, while preserving the capability for collective defense (NATO Handbook, 1998: 16). Building strategic partnerships with the countries in Central and Eastern Europe and the members of the recently established Commonwealth of Independent States, the Russian Federation in particular, was another key factor for the successful transformation of NATO.

\section{The question if NATO needs to expand}

2.1 Change of attitude in periods

From the very beginning the establishment of partnership relations significantly influenced the future enlargement of the Alliance in Central and Eastern Europe. If until 1997 NATO had mostly concentrated on the partnership approach both on a bilateral level (Charter on a Distinctive Partnership between the North Atlantic Treaty Organization and Ukraine 1997 or the Founding Act on Mutual Relations, Cooperation and Security between NATO and the Russian Federation signed in Paris, 1997) or a multilateral level (Partnership for Peace program and the Mediterranean Dialogue, both initiated in 1994), so the period after 1997 was mostly focused on the membership of the post-communist states of Central and Eastern Europe, and the first membership aspirations of the post-Soviet states of Ukraine and Georgia. In June 2017 Montenegro became the most recent NATO Member State.

Although NATO did not admit new Member-States during the first period, the period itself may be divided into two sub-periods depending on the change in the attitude towards possible enlargement of the Alliance. The first sub-period extended from 1990 to 1994 when the overwhelming opinion within the North Atlantic Council is that NATO should not expand, while the second one spanned the time between 1994 and 1997 when the necessity of enlargement became increasingly obvious. 


\subsection{Arguments against enlargement - Trevor Taylor}

Special mention deserves Trevor Taylor (Taylor, 1991), Head of the International Security Program at the Royal Institute of International Affairs in London in 1990-1993, who in his statement in October 1991 described in detail the main concerns of the leading figures in NATO from a potential eastward enlargement of the Alliance in the future:

- First, extending NATO eastward could cause future governments of Russia to fear that the West sought domination over them. It would then make Moscow reluctant to embark on the defense spending cuts which are needed for Russia to achieve economic advance, and it could contribute to the establishment of a strong military influence on the government of the new independent Russia. Further nuclear disarmament would become more difficult and needed partnership between Russia and the West on issues including the proliferation of nuclear and conventional arms would become more elusive.

- Second, admitting Central European states as NATO members would be very disruptive of the Alliance's level of integrity. Since 1950, NATO had been operating on the basis that there should be an equal commitment to the defense of all the territory of allies. As a result, command structures had been put in place, infrastructure elements such as pipelines and airfields had been built, forces from a range of allies had been deployed forward, multinational exercises had been held, and guiding strategy had been laid down.

- Making Poland, the $\mathrm{CSFR}^{3}$ and Hungary credible NATO members would thus involve the forward stationing of at least nominal US and West European forces in Poland, the CSFR and Hungary and the preparation and maintenance of plans for their rapid reinforcement, the construction of infrastructure arrangements and so on. Apart from any political problems, this could be interpreted as illegal under the Conventional Forces in Europe (CFE) Treaty.

- Third, NATO countries lacked the resources to extend their defense commitments. Their publics wanted to spend less on defense and taking formal responsibility for the security of Central Europe would be an additional burden which falling Western defense budgets could not bear.

- Fourth, a serious debate about membership could well split the Alliance. Some members would be extremely wary of making a new commitment in which they felt there was even a remote chance that they could get involved in a nuclear war for the defense of Central Europe. Since NATO decisions required consensus, a proposal for new members, or for new sorts of member, could generate a politically damaging debate and yet not lead to membership suggestions being accepted.

- Fifth, if three countries could become formally associated with NATO, others (for instance Bulgaria or at some later stage Latvia or the Ukraine) would want the same status. Already the political liaison dialogue with Romania and Bulgaria was of a similar degree of intensity as it is with Central European states. It would not be easy in political terms to hold the line at just three new members.

- Sixth, should NATO acquire Poland, the CSFR and Hungary as members, it might at some future point find itself being drawn into ethnic disputes crossing state borders in Central Europe.

Trevor Taylor also expressed the doubt that Poland, the CSFR and Hungary were in any apparent danger at that particular moment (Taylor, 1991). He pointed out that even the Soviet coup leaders in their brief period in power were anxious to stress that they would abide by existing international commitments. The last Soviet forces had already left the CSFR and Hungary. There were still about 40,000 Soviet personnel in Poland but their withdrawal would most likely have been sped with the new regime in Moscow (author's note: the last Soviet troops left Poland in September 1993). Also, with Belarus and Ukraine on the road to full sovereign statehood (author's

3 The Czech Republic and Slovakia since January 1993. 
note: finalized in December 1991) to go with their extant UN membership, the three countries of Central Europe would no longer have a military superpower on their immediate borders.

Instead of future membership in NATO, Trevor Taylor proposed enhancing the political dialogue with all the former members of the Warsaw Treaty Organization, continuing the process of arms reduction, making an official statement that NATO would not tolerate military aggression against any country in Central Europe, as well as encouraging Poland, the CSFR and Hungary to build up their own defense capabilities in postures which are effective without being provocative to their neighbors (Taylor, 1991).

As an alternative to NATO enlargement, there were at least three possible political strategies. The first alternative, favored above all by Russia, was for Russia and NATO to give security guarantees to the countries in Central and Eastern Europe. The second alternative could be the setting up of a sub-regional security system based, for example, on the Visegrád Group. The third alternative, promoted by Russia as well, would be to establish a pan-European security organization based on the OSCE (Pieciukiewicz, 1996/1997). Neither the leading political circles in NATO, nor the governments of the Central European states were interested in solutions such as these.

\subsection{Arguments against enlargement - Russia and the supposed "promise" of Western leaders not to expand NATO. Debunking of the myth}

In his memoirs the distinguished Russian politician and diplomat Yevgeny Primakov also pointed out that according to the Russian archives a number of Western leaders during that period had expressed their disagreement on any future enlargement of NATO beyond Eastern Germany (Primakov, 2000). He went even further by advocating the widely popular in Russia theory that, as a compensation for the reunification of Germany, the leaders of the Western countries had promised NATO would never expand eastward (Primakov, 2000). Another Russian diplomat - Valentin Falin - shared the same view (Falin, 2015). However, other analysts proved in their research that during the negotiations between the Soviet Union and the West in 1990 on the German reunification only two main assurances were offered to Moscow. They concerned the 'special military status' of the territory of the former GDR and the large amounts of funding that would be transferred from the Federal Republic to the USSR, ostensibly to offset the 'costs' of German reunification for the USSR, including the expenses of Soviet troop withdrawals (Kramer, 2009).

One of the most important aspects of the negotiations - the "nine points" presented by Baker to Gorbachev - included the transformation of NATO, strengthening European structures, keeping Germany non-nuclear, eschewing any NATO deployments in Eastern Germany during a specified transition period, granting of a respectable transition period for the withdrawal of all Soviet troops from German territory, and taking Soviet security interests into account. However, they did not mention any guarantee preventing NATO from admitting more countries as members. A more recent research (Savranskaya \& Blanton, 2017) showed that multiple Western leaders and researchers indeed considered the pros and cons of a possible Central and Eastern European membership in NATO as of early 1990 and through 1991. For example, inside the U.S. government, opinions differed, but the suggestion from the Defense Department as of 25 October 1990 was to leave "the door ajar" for East European membership in NATO (Dobbins, 1990, 25 October). The view of the State Department was that NATO expansion was not on the agenda, because it was not in the interest of the U.S. to organize "an anti-Soviet coalition" that extended to the Soviet borders, not least because it might reverse the positive trends in the Soviet Union (Dobbins, 1990, 22 October). The Bush administration took the latter view. And that's what the Soviets heard. 
However, such discussions did little to incorporate any written guarantees against possible NATO enlargement beyond East Germany during the official negotiations with the USSR, not least as the Soviets themselves did not ask for such a thing. Primakov himself underlined this weakness in the Russian interpretation of the results of the negotiations (Primakov, 2000). Moreover, there have not been any debates whatsoever on this issue within the North Atlantic Council, and Article 10 was not changed in any way to forbid further enlargement of the Alliance.

Eventually, it is safe to assume that in 1990 the Soviet Union didn't raise the issue of NATO enlargement except in connection with Eastern Germany. Gorbachev did for a long while seek assurances that Germany would be kept out of NATO, but he failed to receive them. The West German and U.S. governments stuck by their position that Germany should be a full member of NATO and the Soviet leader ultimately backed down on the issue. In a 2014 interview Gorbachev said that the topic of "NATO expansion" as such was 'not discussed at all', although he maintained that the decision to expand NATO into the east was a "violation of the spirit of the statements and assurances made to us in 1990' (Kórshunov, 2014).

In any case, back in 1990 a possible enlargement in the East was not a priority of the Alliance. Only after a few years, however, a combination of internal and external factors triggered a change in the prevailing opinion that such enlargement would be unnecessary or even harmful for the Alliance.

3. The need for enlargement becomes visible

\subsection{The active signals from Central and Eastern Europe}

First, Poland and Hungary have been maintaining active contacts with NATO since 1990. Poland established diplomatic ties with NATO as early as March 1990. Only half a year later (in November 1990) the Polish representative was appointed as a special member of the Political Committee of the North Atlantic Assembly of NATO (author's note: NATO Parliamentary Assembly since 1999) (Boyadjieva, 2013). Such an appointment of a representative from a non-member country was unheard of in the entire previous practice of the Alliance. When Poland took the initiative for establishing long-term political contacts with NATO, other members of the Warsaw Treaty soon followed suit. In June 1990 the foreign minister of Hungary Géza Jeszenszky made a personal visit to the Brussels' headquarters, the first time for a government member to do so (History of Hungarian-NATO relations). In November 1990 Bulgaria also sent a special parliamentary delegation to meet NATO Secretary General Manfred Wörner in Brussels (Memorandum Concerning the Visit of Bulgarian Parliamentarians to NATO, 1990). The delegation members informed him of the ongoing political reorientation of Bulgaria. At the beginning of 1991 a group called "Friends of NATO" was formed within the Bulgarian National Assembly and, along with the Atlantic Club of Bulgaria, began pursuing opportunities for Bulgarian membership in NATO (Boyadjieva, 2013). Since 1991 meetings between representatives of government, parliament and military from the former Warsaw Treaty members with their colleagues from NATO countries became more frequent. In March 1992, during a visit to Poland, NATO Secretary General Manfred Wörner said that "NATO's door is open" (Poland's road to NATO). In the meantime, the deteriorating political situation in several countries in Eastern Europe proved very soon that the Alliance would mostly benefit rather than suffer harm by admitting new members.

\subsection{The political crisis in Russia}

One of the countries with very serious political hardships was the Russian Federation. For two years, the Russian people and the Russian government grudgingly accepted the strategy 
of President Boris Yeltsin for rapprochement with the West. But in 1993, when Yeltsin visited Poland and the Czech Republic and granted at least tacit approval for the first round of NATO enlargement, he drew fierce criticism back home, especially from the Russian Parliament and military officers. Far from an opportunity, these two groups saw the enlargement of their former adversary as a direct threat to Russia's security. Russia's Intelligence Service (SVR) held a similar view. In a report it issued in late 1993, NATO was referred to as the "biggest military grouping in the world that possesses an enormous offensive potential." As a result, apparently under pressure from his armed forces and leading political circles, Boris Yeltsin sent a letter to President Clinton opposing any expansion of NATO to include East European nations like Poland or the Czech Republic (Smith, 2008; Primakov, 2000; Perlez, 1993; Cohen, 1993). But this was only one of the grievances the Russian Parliament held against Yeltsin - many of its members openly criticized the economic and political reforms of the President. Eventually, even before he sent the aforementioned letter to Clinton, Yeltsin decided to take drastic measures against the opposition at home. On 21 September 1993, the President aimed to dissolve the country's legislature, triggering in this way a whole 13-day-long political standoff between him and the Parliament. Eventually, the most serious constitutional crisis in post-Soviet Russia was put to an end after the military intervened in Yeltsin's favor. But this conflict proved that democratic reforms in Russia were not irreversible and further stimulated the desire of Central European countries to join NATO.

\subsection{NATO and the conflict in Bosnia and Herzegovina}

In addition to that, with or without new members, NATO really found itself involved in an ethnic conflict in Eastern Europe - the devastating war that broke out during the breakup of former Yugoslavia. The intervention of NATO in the conflict started as a series of naval blockade and no-fly zone operations in the Adriatic Sea and over the airspace of Bosnia and Herzegovina in support of several UN resolutions including 713, 752, 757, 781 and 787 among others. However, due to the high number of violations of the no-fly zone over Bosnian airspace, the intervention of NATO gradually escalated with Operation Deny Flight (12 April 1993 - 20 December 1995) which gave NATO "all measures necessary" to enforce a more stringent no-fly zone, and with Operation Deliberate Force (30 August - 20 September 1995) which targeted at the Army of Republika Srpska whose presence in Bosnia posed a danger to United Nations "safe areas". The latter two operations played a key role in ending the war. The IFOR (1995-1996) and SFOR (1996-2004) were also created under NATO leadership in order to ensure ending of hostilities, stabilization of peace, establishment of a central Bosnian government and contribution to a secure environment. Central European countries gave strong backing to NATO's operations and proved to be valuable allies to the organization.

\subsection{The decision for NATO enlargement is made}

All these circumstances influenced the policies that were adopted in January 1994 at the NATO Summit in Brussels, which marked a turning point for the transformation of the Alliance. Most prominent among the decisions taken at this Summit was the unveiling of the Partnership for Peace initiative. This was an open invitation to states participating in the North Atlantic Cooperation Council (NACC) and other CSCE (OSCE since 1995) states to join NATO countries in a wide-ranging program of practical cooperation designed to further the capability of working together in undertaking peacekeeping, crisis management and humanitarian tasks (NATO Handbook, 1998: 16-17).

At the Brussels Summit Allied leaders also reaffirmed that the Alliance was open to membership of other European states in a position to further the principles of the Washington 
Treaty and to contribute to security in the North Atlantic area (NATO Handbook, 1998: 81), thus giving start of the second sub-period (1994-1997) concerning the future NATO enlargement. Allied leaders looked forward to welcoming new members into the Alliance as part of an evolutionary process taking into account political and security developments in the whole of Europe.

Somewhat surprisingly, those statements generated little reaction inside Russia until U.S. president Bill Clinton, later that same year, recognizing the political currency that NATO enlargement held for him both at home and abroad, began emphasizing that NATO enlargement would "not depend upon the appearance of a new threat in Europe" (Smith \& Timmins, 2001). In other words, regardless of what Russia did - positively or negatively - enlargement would move ahead (Smith, 2008).

\section{The issues of NATO enlargement}

\subsection{The Study on NATO enlargement}

Following a decision by Allied Foreign Ministers in December 1994, the "why and how" of future admissions into the Alliance was examined by the Allies during 1995. The resulting Study on NATO enlargement was shared with interested Partner countries in September 1995 and made public. The principles outlined in the Study remain the basis for NATO's open approach to inviting new members to join. With regard to the "why" of NATO enlargement, the Study concluded that, with the end of the Cold War and the disappearance of the Warsaw Treaty, there was both a need for and a unique opportunity to build an improved security in the whole of the Euro-Atlantic area, without recreating dividing lines (NATO Handbook, 1998: 81). The Study drew conclusions that were a far cry from the assumptions made by Trevor Taylor several years earlier.

The Study further concluded that the enlargement of the Alliance would contribute to enhanced stability and security for all countries in the Euro-Atlantic area in numerous ways. It would encourage and support democratic reforms, including the establishment of civilian and democratic control over military forces. It would foster the patterns and habits of cooperation, consultation and consensus building which characterized relations among the then Allies and would promote good-neighborly relations in the whole Euro-Atlantic area. It would increase transparency in defense planning and military budgets, thereby reinforcing confidence among states, and would reinforce the tendency toward integration and co-operation in Europe. Furthermore, it would strengthen the Alliance's ability to contribute to European and international security and support peacekeeping under the UN and OSCE; and would strengthen and broaden the transatlantic partnership (NATO Handbook, 1998: 82).

With regard to the "how" of enlargement, the study confirmed that, as in the past, any future extension of the Alliance's membership would be through accession of new member states to the North Atlantic Treaty in accordance with its Article 10. Once admitted, new members would enjoy all the rights and assume all obligations of membership under the Treaty. They would need to accept and conform to the principles, policies and procedures adopted by all members of the Alliance at the time that they joined. The Study made clear that willingness and ability to meet such commitments, not only on paper but in practice, would be a critical factor in any decision taken by the Alliance to invite a country to join (NATO Handbook, 1998: 82).

The Study also noted that the ability of interested countries to contribute militarily to collective defense and to peacekeeping and other new missions of the Alliance would be a factor in deciding whether to invite them to join the Alliance. Ultimately, the Study concluded, Allies would decide by consensus whether to invite each new member to join, basing their decision on their judgement - at the time such a decision has to be made - of whether the membership of a specific country would contribute to security and stability in the North Atlantic area or not. No 
country outside the Alliance had or would have a veto or "droit de regard" over the process of enlargement or decisions relating to it (NATO Handbook, 1998: 82-82).

\subsection{Overcoming the Russian reluctance}

Undoubtedly, the last part addressed indirectly the traditional Russian reluctance if not outright protest against any plans for NATO enlargement eastward. However, on the eve of NATO Madrid Summit in July 1997, Alliance's continuing effort to build partnership with the Federation marked significant progress. On 27 May 1997, in Paris, the Allied leaders and Russian President Yeltsin signed the Founding Act on Mutual Relations, Cooperation and Security between NATO and the Russian Federation. This Founding Act not only created a mechanism for consultation and cooperation - the NATO-Russia Permanent Joint Council (PJC) - but also set out specific areas of mutual interest in which NATO and Russia could build a solid, effective and enduring partnership (NATO Handbook, 1998: 18). In exchange, Yeltsin officially blessed the first round of NATO enlargement to Poland, the Czech Republic, and Hungary in 1997 (Smith, 2008). Yeltsin made clear, however, that Russia strongly opposed additional rounds of enlargement, especially to the Baltic countries. This new 'red line' ran along the borders of the former Soviet Union ${ }^{4}$.

\subsection{The first enlargement of NATO is achieved}

Considering the conclusions of the Study and the signing of the NATO-Russia Founding Act, it was only a matter of time before the first round of NATO enlargement came about. NATO Madrid Summit in July 1997 marked a decisive phase in the process of transformation of the Alliance. During the forum Allied Heads of State and Government invited the Czech Republic, Hungary and Poland to begin accession talks with NATO. Following this decision, negotiations took place with each of the invited countries in the autumn of 1997 and Accession Protocols for each of the three were signed in December 1997. The three countries officially became members of the Alliance in March 1999.

\section{Results of the first NATO enlargement}

It is important to note that NATO enlargement is an open, continuing process, not a single event. In Madrid the Allies once again underlined that NATO remains open to new members under Article 10 of the North Atlantic Treaty and that the Alliance will continue to welcome new members in a position to further the principles of the Treaty and to contribute to security in the Euro-Atlantic area. It should be noted that in March 1997 the caretaker government of Stefan Sofiyanski also applied for full membership in NATO.

NATO enlargement did not result in weakened cooperation between the countries in Central and Eastern Europe, as many critics had feared. Quite the opposite, the prospect of membership helped consolidate democracy in Central Europe, strengthen free market reform and encourage NATO aspirants to settle disputes with their neighbors. The newcomers did not want to "close NATO's door". They became advocates of further enlargement. The vision of NATO membership and conditionality of enlargement was another impulse to intensify the already existing cooperation in the region. In 1994, the Good Neighborly Relations and Military Cooperation Agreement was concluded between Poland and Lithuania, in 1996 the Treaty on Good Neighborliness and Friendly Cooperation between Hungary and Slovakia was signed, as was the

\footnotetext{
${ }_{4}$ Still, the new "red line" lasted only until 2004, when seven other European countries, including Bulgaria
} and the Baltic states, also became members of the Alliance. 
Bilateral Defense Cooperation Agreement between Hungary and Slovenia and Bilateral Friendship Treaty between Hungary and Romania, and in 1997 the Treaty of Friendship and Cooperation between Romania and Ukraine was concluded (The debate over NATO expansion, 1997).

NATO's policy of enlargement had a positive influence on the consolidation of the newly founded democracies in Central and Eastern Europe and the establishment of new level of cooperation between them. In this way the enlargement of NATO influenced in a positive way the security environment in the whole of Europe. On the other hand, NATO also benefited from its new members, meaning that the new members successfully contributed to the North Atlantic Alliance. First, all of them offered significant geopolitical space to NATO in form of the availability of their territories. Second, the new members extended political and military support to Allied international missions by contributing with people, experts, suggestions and specific viewpoints (Starova, 2015).

\subsection{Concluding remarks}

The evolution of the 1990-1997 NATO enlargement concept and the experience of the accession of Poland, the Czech Republic and Hungary to the Alliance in 1999 paved the way for another three rounds of enlargement (in 2004, 2009 and 2017). As a result, 10 more countries joined NATO. For them, membership in the Alliance meant accomplishing a strategic foreign policy goal and strengthening their stability and security. On the other hand, the enlargement contributed to NATO's own capabilities in the new security environment after the end of the Cold War. Due to this interdependence, NATO's door remains open for all European democracies, which are willing and able to assume membership responsibilities and whose inclusion can contribute to common security and stability.

\section{Acknowledgements}

I would like to express my very great appreciation to my former PhD Supervisor - the late Prof. Kostadin Grozev - for his valuable and constructive suggestions during the planning and development of this research work. His willingness to give his time so generously has been invaluable. I would also like to thank my current PhD Supervisor - Associate Prof. Alexander Sivilov - who did his best to help me complete the article by virtue of his very much appreciated advice and general support.

I would also like to thank Dr. Solomon Passy, President of the Atlantic Club of Bulgaria and Bulgarian Foreign Minister (2001-2005), who readily shared with me his memories about the time period and let me use his personal archive.

\section{References}

Boyadjieva, N. (2013). Russia, NATO and the security environment after the Cold War, Part I, 1989-1999. Sofia: Daniela Ubenova, 91-92. (in Bulgarian).

Cohen, R. (1993, October 2). Yeltsin opposes expansion Of NATO in Eastern Europe. The New York Times. Retrieved 17 March 2017, from http://www.nytimes.com/1993/10/02/world/yeltsin-opposes-expansion-of-nato-in-easterneurope.html. 
Dobbins, J. F. (1990, October 25). NATO strategy review paper for discussion. U.S. State Department, European Bureau. Retrieved 25 March 2018, from

https://nsarchive2.gwu.edu//dc.html?doc=4325705-Document-27-James-F-Dobbins-StateDepartment.

Dobbins J. F. (1990, October 22). Revised NATO strategy paper for discussion at sub-ungroup meeting, U.S. State Department, European Bureau. Retrieved 25 March 2018, from

https://nsarchive2.gwu.edu//dc.html?doc=4325704-Document-26-U-S-Department-ofState-European.

Falin, V. (2015). When we lost Germany: History of USSR's capitulation. Russia in Global Affairs (in Russian). Retrieved 27 October 2017, from

http://www.globalaffairs.ru/diplomacy/Germaniya-kotoruyu-my-poteryali-istoriyakapitulyatcii-Sovetskogo-Soyuza-17687.

Hende, C. (2015). The door should remain open. In: Newcomers No More? (p. 25). International Relations Research Institute in Warsaw, Jagello 2000 - NATO Information Center in Prague, Latvian Institute of International Affairs in Riga in cooperation with the Atlantic Treaty Association in Brussels, Warsaw - Prague - Brussels.

History of Hungarian - NATO relations (2018). Ministry of Foreign Affairs of Hungary. Retrieved 25 March 2018, from http://bit.ly/2xrgGtG.

Kórshunov, M. (2014, October 6). Mikhail Gorbachev: I am against all walls. Russia Beyond. Retrieved 23 March 2018, from

https://www.rbth.com/international/2014/10/16/mikhail gorbachev $\mathrm{i}$ am against all wa

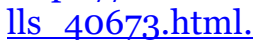

Kramer, M. (2009, April). The myth of a no-NATO pledge to Russia. The Washington Quaterly, 39-61.

Memorandum concerning the visit of Bulgarian Parliamentarians to NATO (1990, November 22). Retrieved 27 October 2017, from

http://www.solomonpassy.com/uploads/articles/bg/filepath_6.pdf (In Bulgarian).

NATO Handbook (1998). Office of information and press of NATO, 16-18, 81-83.

Perlez, J. (1993, August 26). Yeltsin "understands" Polish bid for a role in NATO. The New York Times. Retrieved 27 March 2017, from

https://www.nytimes.com/1993/08/26/world/yeltsin-understands-polish-bid-for-a-role-innato.html.

Pieciukiewicz, T. (Winter 1996/1997). Security in Central and Eastern Europe: A view from Warsaw. InParameters, 4, 130-131.

Poland's road to NATO (2018). Ministry of Foreign Affairs of Poland. Retrieved on March 25, 2018, from http://bit.ly/2goOias.

Primakov, Yev. (2000). Years in Big Politics. Sofia, BRIP Ltd., 210, 215-217 (in Bulgarian).

Savranskaya, Sv., \& Blanton, T. (2017, December 12). NATO Expansion: What Gorbachev heard. National Security Archive, Briefing Book \#613. Retrieved 25 March 2018, from https://nsarchive.gwu.edu/briefing-book/russia-programs/2017-12-12/nato-expansionwhat-gorbachev-heard-western-leaders-early.

Smith, J. (2008). The NATO-Russia relationship. Defining moment or Déjà Vu? Center for Strategic \& International Studies, 2-4.

Smith, M. A., \& Timmins, G. (2001). Russia, NATO, and the EU in an era of enlargement: Vulnerability or opportunity? Geopolitics, 6(1), 73.

Starova, A. (2015). NATO's enlargement as a great contribution to international freedom, peace and security. In: Newcomers No More? (pp. 52-53). International Relations Research Institute in Warsaw, Jagello 2000 - NATO Information Center in Prague, Latvian Institute of 
International Affairs in Riga in cooperation with the Atlantic Treaty Association in Brussels, Warsaw - Prague - Brussels.

Taylor, T. (1991, October). NATO and Central Europe. NATO Review, Web Edition, 39(5), 17-22. Retrieved 23 March 2017, from http://www.nato.int/docu/review/1991/9105-4.htm.

The debate over NATO expansion: A critique of the Clinton Administration's responses to key questions. (1997, September). Arms Control Association. Retrieved 17 March 2017, from https://www.armscontrol.org/act/1997 09/nato. 
A. Y. Apostolov - Evolution of the Concept of NATO Enlargement in the Period 1990-1997

C O A $\mathbf{s}$ 